\title{
As figuras da amizade em Kant e suas relações com a Moral, o Direito e a Política
}

\author{
Alexandre Travessoni Gomes \\ travessoni@superig.com.br \\ Universidade Federal de Minas Gerais e Pontifícia Universidade Católica-Minas, \\ Belo Horizonte, Minas Gerais, Brasil
}

resumo Este ensaio aborda o conceito de amizade em Kant, e procura relacioná-lo com a moral, o direito e a política kantianos. Como forma de introduzir a temática, começa o texto com uma abordagem do conceito e dos tipos de amizade apresentados por Aristóteles. Após isso, aborda o conceito e os tipos de amizade apresentados por Kant, tanto na Doutrina da Virtude (A Metafísica dos Costumes) quanto nas Preleções sobre Ética. 0 texto trata então dos problemas e das vantagens que o conceito kantiano de amizade representa, para, por fim, procurar, sob inspiração de Aristóteles, aproximar a temática da amizade em Kant de suas filosofias moral, jurídica e política.

palavras-chave amizade; direito; moral; política; Kant; Aristóteles

\section{A amizade em Aristóteles}

A amizade aparece como tema privilegiado na Ética a Nicômaco de Aristóteles. Nessa obra, já no livro II, antes mesmo de entrar diretamente no tema da amizade, (o que só será feito no livro VIII), ao tratar do conceito e da natureza da virtude é dito que "na alma se encontram três espécies de coisas - paixões, faculdades e disposições de caráter” (ARISTÓTELES, 1991, p. 31), e que as paixões são "os apetites, a cólera, o medo, a audácia, a inveja, a alegria, a amizade, o ódio, o desejo, a emulação, a compaixão e em geral os sentimentos que são acompanhados de prazer ou dor" (ARISTÓTELES, 1991, p. 31). Após isso, Aristóteles afirma que as faculdades são "as coisas em virtude das quais se diz que somos capazes de sentir 
tudo isso" (ARISTÓTELES, 1991, p. 31), isto é, todas as paixões antes mencionadas. Não sendo as virtudes, segundo Aristóteles, nem paixões nem faculdades, só podem ser elas disposições de caráter (ARISTÓTELES, 1991, p. 31-32), disposições que tornam o homem bom e o fazem desempenhar bem sua função (ARISTÓTELES, 1991, p. 32), ou seja, disposições relacionadas à escolha (ARISTÓTELES, p. 1991, 33).

Essa caracterização da amizade como paixão, ao lado do medo, da cólera, da inveja, da alegria etc., soa no mínimo estranha. A amizade parece ser, já em Aristóteles, um modo de agir, uma espécie de relação. Não é à toa que, no Livro VIII, ao entrar especificamente no tema da amizade, Aristóteles vacila e não a coloca expressamente como paixão; após tratar, no final do Livro VII, do prazer e da dor, Aristóteles afirma: "depois do que dissemos segue-se naturalmente uma discussão da amizade, visto que ela é uma virtude ou implica virtude, sendo, além disso, sumamente necessária à vida" (ARISTÓTELES, 1991, p. 139). Por um lado, talvez Aristóteles tenha primeiramente afirmado ser a amizade uma paixão por estar ela relacionada ao amor, o que ele expressamente admite no Livro VII. Por outro lado, a relativa identificação ou pelo menos relação da amizade com a virtude parece decorrer do fato de ela de algum modo se relacionar com nossas escolhas. Como o objeto principal deste ensaio não é a amizade em Aristóteles, não me aprofundarei nesse tema conceitual, limitando-me a identificar, a partir de agora, elementos sobre a amizade abordados por Aristóteles que possam de algum modo embasar a ulterior discussão sobre a amizade em Kant, que pretendo realizar. Como se perceberá ao longo do texto, embora existam muitas diferenças entre o tratamento dado por Aristóteles e por Kant à questão da amizade, há, em outros, um paralelismo que chega a surpreender o leitor, sobretudo quando se considera não só a distância cronológica entre os dois autores, mas também os contextos históricos extremamente diferenciados em que produziram suas obras.

Chama atenção no tratamento da amizade em Aristóteles a necessidade da reciprocidade: no ponto 2 do Livro VII, ao tratar dos vários empregos da palavra amor, Aristóteles afirma que para o amor que os homens têm pelos objetos inanimados não se utiliza a palavra amizade, pois não se trata de amor mútuo. Mas mesmo quando há amor por um ser humano, parece não ser o caso necessariamente de amizade, pois mesmo 
quando se deseja o bem de alguém no interesse dele próprio pode se tratar de mera benevolência, se o desejo não é recíproco. Portanto, para que se configure amizade, não basta o desejo, por parte de um, do bem de outro; é preciso que o outro também lhe deseje o bem e, mais ainda, é preciso que além do desejo recíproco exista o conhecimento recíproco do desejo alheio. Esse parece ser o sentido da seguinte afirmação de Aristóteles: "a fim de serem amigas, pois, devem conhecer uma à outra como desejando-se bem reciprocamente", não podendo, portanto, ignorar seus sentimentos mútuos (ARISTÓTELES, 1991, p. 140).

Não basta portanto querer o bem de alguém para que exista amizade. "A benevolência é uma espécie de relação amigável, mas não se identifica com a amizade, pois que tanto podemos senti-la para com pessoas a quem não conhecemos como sem que elas próprias o saibam, ao passo que com a amizade não sucede assim”, podendo ser a benevolência compreendida então, quando muito, como o começo da amizade (ARISTÓTELES: 1991, 164-165).

Essa reciprocidade significa que a amizade é uma espécie de amor mútuo, amor esse que decorre de razões diferentes, que possibilitam, na visão da Aristóteles, a classificação da amizade em três tipos: (a) há aqueles que se amam mutuamente em virtude da utilidade, (b) há aqueles que se amam mutuamente em virtude do prazer, e, por fim, (c) há aqueles que desejam igualmente o bem um ao outro, sendo bons também em si mesmos (ARISTÓTELES, 1991, p. 141). A primeira espécie de amizade, a amizade de utilidade, não é duradoura, pois, como o que é útil não é permanente, desaparecendo a utilidade desaparece também a amizade. Segundo Aristóteles esse tipo de amizade é comum entre os velhos, que, de modo geral, preferem o útil ao agradável, enquanto os jovens, por outro lado, preferem o prazer, pois eles são guiados pela emoção e buscam acima de tudo o que lhes agrada (ARISTÓTELES, 1991, p. 141). A amizade com vistas à utilidade ou ao prazer é possível entre os maus, ou mesmo entre bons e maus (ARISTÓTELES, 1991, p. 143). Porém a verdadeira amizade ou amizade perfeita é a amizade entre os bons, ou seja, a amizade que se funda na bondade mútua, amizade em sentido absoluto e não meramente relativo como as demais (ARISTÓTELES, 1991, p. 14).

É importante notar que nas três espécies de amizade há não só a necessidade da reciprocidade, isto é, do reconhecimento recíproco do outro 
como meu amigo em um dos três sentidos acima, mas também a idéia de retribuição. $\mathrm{Na}$ amizade com vistas à utilidade eu me relaciono com alguém porque isso é de algum modo útil para mim, ao que retribuo com alguma prestação útil ao amigo. Podemos dizer que as relações de coleguismo constituem muitas vezes amizade com vistas à utilidade, amizade essa que Aristóteles afirma ser uma amizade num sentido quase comercial. $\mathrm{Na}$ amizade com vistas ao prazer, também há a idéia de retribuição, pois em troca do prazer que recebo na relação com alguém lhe propicio algum prazer. O que é interessante notar é que, mesmo na verdadeira amizade, a amizade dos bons ou amizade absoluta, há também não só a idéia de reciprocidade, mas também a de retribuição: o homem bom retribui o tratamento bondoso, isto é, ser objeto da bondade do amigo, com a mesma bondade. Se, por um lado, esse raciocínio parece colocar a amizade em um terreno puramente estratégico, por outro lado ele tem um aspecto positivo, pois quando tenho um amigo em sentido absoluto há o reconhecimento recíproco da personalidade de cada um, isto é, há o reconhecimento que ambos somos pessoas e não coisas, já que o homem bom "se relaciona para com seu amigo como para consigo mesmo (pois o amigo é um outro "eu")" (ARISTÓTELES, 1991, p. 164). Não é por outra razão que Aristóteles admite a amizade com um escravo, não enquanto escravo, mas enquanto homem!

É interessante notar ainda, no que diz respeito à retribuição, que Aristóteles levanta a possibilidade de combinação das espécies de amizade, isto é, a possibilidade, por exemplo, de uma pessoa ser verdadeira amiga de outra enquanto essa outra é amiga da primeira com vistas à utilidade. Segundo Aristóteles, essa amizade obviamente não poderá durar muito.

Um tópico que se conecta às questões do reconhecimento, da reciprocidade e da retribuição é o do amor próprio. Aristóteles pergunta se as pessoas devem amar a si mesmas acima de todas as coisas (ARISTÓTELES, 1991, p. 167), ao que reponde afirmando que embora pareça à primeira vista que o homem deve amar seu amigo acima de si mesmo, isso

não é, em seu entendimento, necessariamente verdade. É preciso, segundo Aristóteles, distinguir dois sentidos diversos em que a expressão amigo de si mesmo é usada. Um primeiro sentido da autofilia é um sentido negativo, em que ela denota aquelas pessoas que desejam muitas riquezas, honras e prazeres corporais, por elas competindo com os demais. São amigos de si 
mesmos nesse sentido negativo aqueles que, no dizer de Aristóteles "satisfazem seus apetites e, de modo geral, os seus sentimentos e o elemento irracional da alma" (ARISTÓTELES, 1991, p. 168). Segundo Aristóteles, o homem que age com temperança e justiça, ou de acordo com qualquer outra virtude, procurando assumir para si a conduta mais nobre, geralmente não é chamado amigo de si mesmo, mas deveria, pois atribui a si as coisas mais nobres e melhores, satisfazendo o elemento mais valioso de sua natureza (ARISTÓTELES, 1991, p. 168). Há, pois, na visão de Aristóteles, um segundo sentido para a expressão amigo de si mesmo, sentido esse que, ao contrário do primeiro, é um sentido extremamente positivo e que, embora não muito utilizado, é o verdadeiro e próprio sentido da expressão. Naturalmente, ser amigo de si mesmo nesse segundo sentido é algo que não só não é reprovável, como também é louvável.

Outra questão importante ainda em Aristóteles é referente à quantidade de amigos que alguém deve ter: devemos fazer o maior número possível de amigos? Aristóteles afirma, logo de início, que tanto à amizade que fazemos com vistas à utilidade quanto à amizade que fazemos com vistas ao prazer aplica-se a analogamente a máxima "não ser homem de muitos convidados, nem homem de nenhum”, pois, no que diz respeito à utilidade, retribuir serviços de muita gente é "coisa trabalhosa e uma vida humana não basta para tanto", o mesmo valendo para as amizades com vistas ao prazer (ARISTÓTELES, 1991, p. 172). No que diz respeito aos bons amigos, ou seja, à amizade em sentido absoluto, Aristóteles afirma, também analogamente, que assim como "não se pode fazer uma cidade com dez homens, e se estes forem cem mil nem por isso ela será uma cidade", também o melhor número de amigos não é necessariamente nem o maior nem o menor em termos absolutos, mas um meio termo entre eles: o maior com que se possa conviver. E sendo evidente que não se pode conviver com muitas pessoas dividindo-se entre elas, Aristóteles entende que não podemos amar várias pessoas ao mesmo tempo, e que convém portanto não procurar ter o maior número de amigos possível, mas apenas tantos quantos forem suficientes para os fins do convívio (ARISTÓTELES, 1991, p. 172).

Até aqui, todas as questões tratadas por Aristóteles parecem estar no plano ético, não adentrando assim a política. Isso não quer dizer que a amizade não seja um conceito ligado à política: certamente ela o é, pois o 


\section{2}

homem como ser político precisa se relacionar com os demais. Mas nos temas abordados até aqui a amizade se relaciona com a política apenas na medida em que a ética de modo geral se relaciona com a política. Há porém pelo menos duas passagens na própria Ética a Nicômaco em que essa relação parece ser analisada mais detidamente: uma delas está no livroVIII, quando Aristóteles compara as formas de amizade às formas de governo, dizendo que assim como há três formas puras ao lado de três formas deturpadas de constituição, a saber, Monarquia, Aristocracia e a Timocracia, ou seja, o governo de um, o governo de alguns e o governo que se baseia na posse de bens, ao lado da Tirania, da Oligarquia e da Democracia, isto é, o governo de um que visa somente sua própria vantagem, o governo de alguns que distribuem a maior parte das coisas boas para si mesmos e o governo da maioria que só pensa em si (ARISTÓTELES, 1991, p. 149), há, analogamente, três formas de amizade: a amizade entre pai e filho tem a forma de uma Monarquia; a associação entre marido e mulher tem a forma de uma Aristocracia e a associação entre irmãos tem a forma de uma Timocracia (ARISTÓTELES, 1991, p. 150). A segunda passagem, que tem maior importância para o tema aqui estudado, está no Livro IX e se refere ao conceito de unanimidade.

A unanimidade é, na visão de Aristóteles, uma relação amigável. Ela não é entendida como mera identidade de opinião, que poderia ocorrer entre pessoas que não se conhecem, mas sim como identidade de opinião quando as pessoas tratam de algo que é de seu interesse, e então escolhem as mesmas ações e fazem em comum o que resolveram (ARISTÓTELES, 1991, p. 165). Assim, por exemplo, segundo Aristóteles, "uma cidade é unânime quando todos os cidadãos pensam que os seus cargos públicos devem ser eletivos, ou que convém fazer aliança com Esparta, ou que Pítaco deve governá-la - numa ocasião em que o próprio Pítaco também deseje governar" (ARISTÓTELES, 1991, p. 166). Aristóteles conclui então que a unanimidade é a amizade política. Portanto, ao mesmo tempo em que Aristóteles exige para a unanimidade o conhecimento recíproco, ele abranda o caráter desse conhecimento, ou pelo menos o modifica, pois a reciprocidade está não mais em conhecer e amar o amigo como no caso da amizade perfeita, mas sim em compartilhar com os demais membros de uma comunidade política interesses comuns e formas de efetivá-los. Se, por um lado, a amizade em sentido estrito, ou 
seja, a amizade dos bons, não pode ser compartilhada universalmente (ninguém é amigo de todos!), a unanimidade ou amizade política pode ter maior universalidade, justamente por demandar menos dos amigos. Embora o tratamento da amizade política não signifique o abandono da concepção aristotélica de amizade como relação entre um grupo fechado ou determinado de pessoas, o que ocorrerá apenas em Kant, ele certamente constitui um abrandamento do rigorismo dessa concepção.

Vistos (1) alguns pontos essenciais da teoria aristotélica da amizade, que, como se verá, serão importantes para o desenvolvimento dos temas ulteriores, posso agora passar a Kant, abordando mais diretamente o ponto que propus tratar neste ensaio. Para tanto, pretendo primeiramente abordar (2) o conceito e os tipos de amizade em Kant, após o que pretendo efetivar uma (3) análise crítica de sua concepção, baseando-me tanto em pontos de sua filosofia moral, como a distinção entre imperativos hipotéticos e categóricos, quanto em elementos da teoria aristotélica acima sumarizados, para então (4) verificar a relação existente, em Kant, entre a filia e a moral, bem como entre aquela e a política (e o direito).

\section{Conceito e tipos de amizade em Kant}

Na Doutrina da Virtude Kant define a amizade como "a união de duas pessoas através de igual amor e respeito recíprocos" (DV 469). ${ }^{1}$ Como ressalta Korsgaard, enquanto o amor leva alguém a perseguir os fins do outro, o respeito lembra que é o outro quem deve determinar quais são esses fins; enquanto o amor leva alguém a se preocupar com a felicidade do outro, o respeito exige que se preocupe também com seu caráter (KORSGAARD, 2000, p. 191). Kant afirma que é fácil ver que essa noção de amizade é um ideal de comunicação e de participação de cada um no bem do outro, através de uma vontade moralmente boa, ideal esse que, portanto, é na prática inatingível, ou seja, que não produz total felicidade de vida, ainda que o simples fato de as partes assumirem-no já faça que elas mereçam essa felicidade (DV 469). Por isso Kant afirma que buscar esse ideal é um dever indicado pela razão (DV 469).

Como mostra Merle, o conceito inicialmente apresentado por Kant, que é o (a') conceito estético de amizade, ao qual ele oporá, mais adiante, 
o (b’) conceito moral de amizade, já tinha sido apresentado por Wolf, estando a originalidade de Kant na idéia de ligar a perda da amizade a seu próprio exercício: a benevolência em relação ao amigo (MERLE, 2007, p. 38). Ainda segundo Merle, o argumento de Kant se sustenta nas seguintes teses: “(1) A amizade exige (1.1) uma reciprocidade e uma igualdade no amor, a saber, na benevolência entre os dois amigos, assim como (1.2) uma igualdade entre eles no respeito. (2) A amizade exige uma igualdade entre o amor ou benevolência, de um lado, e o respeito a ele, por outro lado. A amizade é pois concebida por Kant como uma tríplice igualdade. (3) O exercício da benevolência constitui-se em um fardo. Da tese (3) decorre a tese (4): o exercício da benevolência reveste o amigo benevolente de um mérito moral, que reivindica o respeito da parte do amigo beneficiado pela benevolência. (5) Aquele que se beneficia da benevolência de seu amigo não tem mérito moral, ao passo que seu benfeitor o tem, de sorte que o exercício da benevolência destrói a igualdade no que concerne ao respeito" (MERLE, 2007, p. 38).

A Doutrina da Virtude considera uma tal amizade estética impossível, tanto do ponto de vista psicológico, quanto do ponto de vista moral. Do ponto de vista psicológico a amizade se torna um fardo pesado, pois, segundo Kant, se por um lado a pessoa deseja um amigo quando está em necessidade, por outro, é extremamente oneroso encarregar-se das necessidades de outra pessoa (DV 470). Do ponto de vista moral, Kant critica a amizade fundada na vantagem mútua, por achar que, em uma união puramente moral a ajuda não deve ser encarada como fim determinante da amizade, mas somente como manifestação externa de uma sincera benevolência interior (DV 470). Segundo Merle, a colocação, por Kant, dos problemas psicológicos e morais da amizade, supõe uma premissa suplementar, "que consiste em restringir o sentido da palavra 'amizade' a uma amizade estável e duradoura, quase perpétua” (MERLE, 2007, p. 42). Ainda no entendimento de Merle, o problema psicológico posto acima não impede que exista a amizade, como a constatamos cotidianamente, mas apenas a torna amoral (MERLE, 2007, p. 42).Voltarei a essa questão abaixo. Antes disso devo tratar da amizade puramente moral.

A amizade moral, segundo Kant, é a "confiança total entre duas pessoas que revelam reciprocamente suas opiniões e sentimentos íntimos, na medida em que tais revelações sejam compatíveis com o respeito 
recíproco" (DV 471). Apesar de ser também insociável, o homem é um ser destinado a viver em sociedade, e por isso sente a necessidade de se abrir com os outros, sentindo-se porém "coibido e advertido também pelo receio do mau uso que os outros possam fazer da revelação dos seus pensamentos", vendo-se portanto "obrigado a reservar para si uma boa parte de seus juízos” (DV 471). Como ressalta Merle, Kant vê dois problemas que ameaçam a amizade moral: (1) "todo o homem tem segredos e não se deve confiar cegamente nos outros" e (2) muitas pessoas (2.1) não têm nobreza, estando dispostas a fazer um mau uso das confidências da outra pessoa ou (2.2) não têm sensatez para julgar e distinguir sobre o que pode ou não ser revelado aos outros (DV 472; MERLE, 2007, p. 43). Kant entende que pessoas com a nobreza e a sensatez referidas acima são raras, assim como, conseqüentemente, será rara a amizade unicamente moral, ou, como diz Juvenal (Sátiras II, 165), "um pássaro raro na terra, semelhante a um cisne negro" (DV 472).

Após tratar da amizade puramente moral Kant insere, no último parágrafo do $\$ 47$ da Doutrina da Virtude, a idéia de amigo da humanidade, um amigo dos homens em geral, aquele que participa esteticamente no bem de todos e que não perturbará esse bem sem profundo pesar (DV 472). A expressão amigo dos seres humanos contém "a representação e o tomar a peito da igualdade entre os homens, portanto, a idéia de que ao obrigar outros com a beneficência se torna ele próprio obrigado; por assim dizer, como se todos os homens fossem irmãos sob o poder de um pai universal, que quer a felicidade de todos" (DV 473).

Por fim, antes de passar à análise dos temas estudados, é necessário tratar da visão que Kant apresenta nas Preleções sobre Ética, pois há nessa obra, pelo menos aparentemente, algumas diferenças em relação à Doutrina da Virtude. Kant afirma que "os homens se movem por dois tipos de estímulo: um é o amor por si mesmo e o outro é o amor pela humanidade" (PE 422). Kant afirma ainda que esses dois estímulos muitas vezes se acham em conflito: devo preocupar-me em primeiro lugar com minha felicidade e então só depois tentar propiciar a felicidade dos demais ou o contrário? Ora, se busco minha felicidade em primeiro lugar corro o risco de nunca buscar a felicidade dos demais, pois o processo de busca da minha felicidade nunca se completa; se, por outro lado, começo preocupando-me pela felicidade dos outros, ficará deixada de lado minha 


\section{6}

própria felicidade ( $\mathrm{PE} \mathrm{422).} \mathrm{O} \mathrm{homem} \mathrm{que} \mathrm{se} \mathrm{ocupa} \mathrm{de} \mathrm{si} \mathrm{próprio} \mathrm{e}$ deixa de lado os outros não viola a moral, desde que não impeça os outros de buscarem sua felicidade, mas também não tem mérito moral algum (PE 422). A amizade é definida, pois, como "o máximo valor da reciprocidade amorosa" (PE 423). Também aqui nas Preleções ela é, segundo Kant, impossível de ser atingida, constituindo-se como idéia (PE 423).

Kant então classifica a amizade em três tipos: (a") a amizade de necessidade ou confiança recíproca para a satisfação de necessidades da existência; (b") a amizade de gosto (ou estética) e (c") a amizade de intenção (PE 424). "A amizade baseada nas necessidades é aquela segundo a qual as pessoas podem contar com uma provisão recíproca no que diz respeito a suas necessidades vitais" (PE 425); “a amizade em sentido estético é na realidade uma pseudoamizade, que busca a complacência do trato e a complacência mútua, mas não a felicidade de ambas as partes” (PE 426). Segundo Kant, esse tipo de amizade ocorre, de modo geral, entre pessoas de ofícios diferentes: um homem de letras não terá esse tipo de amizade com um colega, pois como ambos são capazes de fazer exatamente o mesmo, a conversa entre eles não será interessante (o que um sabe o outro também sabe); mas um homem de letras pode perfeitamente manter esse tipo de amizade com um soldado ou com um comerciante, desde que o primeiro não seja pedante e o segundo não seja estúpido, pois sob essa condição podem conversar um com outro, falando cada um de suas coisas (PE 426). A amizade de intenção ou de sentimento não consiste em exigir algo do outro em troca de um serviço, mas se apóia em puros e sinceros sentimentos (PE 426). Ela acontece quando "participamos ao outro o que sentimos", estabelecendo assim uma relação autêntica (PE 426).

\section{Análise crítica da concepção de Kant}

Posso agora me dedicar a uma análise crítica da teoria da amizade de Kant. Primeiramente, devemos constatar, com Merle, que as teses do argumento de Kant sobre a amizade estética são amorais, ou até mesmo imorais, pois a impossibilidade de tal amizade não é, à primeira vista, moral, mas psicológica.Vejamos. No que diz respeito à primeira igualdade, isto é, a igualdade na benevolência, Merle entende que ela pode dizer respeito à 
máxima das ações do amigo, às próprias ações do amigo ou ao resultado dessas ações. Pode acontecer que eu e meu amigo sejamos igualmente benévolos, isto é, tenhamos a mesma intenção de ajudar um ao outro, mas, por exemplo, devido a minha situação precária eu não possa ajudá-lo (MERLE, 2007, p. 39). Como lembra Merle, segundo o próprio Kant, tanto na Fundamentação da Metafísica dos Costumes quanto na própria Doutrina da Virtude, apenas a máxima da vontade pode ser boa, e a própria máxima da benevolência é por si só já uma base de obrigação para a gratidão (DV 455). O mesmo acontece com a segunda igualdade, isso é, a igualdade de respeito, pois respeito deve ser considerado como respeito pelo ser racional no amigo (BARON, 2003, p. 397), devido portanto não só a ele, mas a todo ser humano, independentemente de ser amigo ou não (MERLE, 2007, p. 39).

Ora, há aqui duas questões diferentes: por um lado, Baron e Merle parecem ter razão quando afirmam que o respeito é devido a todo ser humano. Mais ainda, podemos adicionar que até a benevolência é, para Kant, um dever em relação a todo ser humano (DV 396-400), amigo ou não. Mas o ponto é a questão da reciprocidade. Aristóteles já tinha percebido que a reciprocidade envolvida na amizade significa que ela é uma espécie de amor mútuo. A (a’) amizade estética de Kant igualmente envolve reciprocidade e, mais ainda, o que a impede não são dificuldades morais, mas sim a desproporcionalidade na reciprocidade. Aqui, a análise da (a) amizade de utilidade e (b) de prazer, feita por Aristóteles, pode ajudar. Como vimos, para Aristóteles, na amizade aqueles que se amam mutuamente o fazem (a) em virtude da utilidade, (b) em virtude do prazer, ou, por fim, em (c) virtude de um desejo igual e recíproco do bem um em relação ao outro, sendo bons também em si mesmos (ARISTÓTELES, 1991, p. 141). Aristóteles admite ainda que quando a troca não é mais interessante a amizade se desfaz. O problema de Kant parece ter sido querer dar à (a') amizade estética, que de algum modo corresponde às amizades (a) com vistas à utilidade e (b) ao prazer de Aristóteles, caráter perpétuo. Esses tipos de amizade admitem uma racionalidade estratégica, conforme parece admitir o próprio Kant ao falar do "fardo muito pesado", ou seja, admite que eu trate o outro como meio para satisfação de minhas necessidades. Pode parecer então, à primeira vista, que esses tipos de amizade são não só amorais como imorais, como ressalta Merle. Mas 


\section{8}

se considerarmos a segunda fórmula do imperativo categórico, apresentada por Kant na Fundamentação, e sua aplicação em alguns exemplos da Doutrina do Direito, perceberemos que essa não é uma conclusão necessária. Na Fundamentação Kant distingue os imperativos hipotéticos do imperativo categórico. Ambos são comandos da razão, os primeiros condicionados, o segundo incondicionado (FMC 414). A razão pode ordenar algo de forma condicionada, isto é, pode ordenar algo que é um bom meio para se alcançar determinado fim (FMC 416), ou pode ordenar uma conduta incondicionalmente, isto é, uma conduta que não é meio para se alcançar determinado fim, mas uma conduta que é um fim em si mesmo, porque é boa em si mesma (FMC 416). O primeiro tipo de comandos da razão, os imperativos hipotéticos, são regras de destreza e conselhos da prudência (FMC 415), enquanto o segundo tipo, o imperativo categórico, é o imperativo da moralidade (FMC 416). O imperativo categórico tem três fórmulas: a fórmula da lei universal (FMC 421), a fórmula da humanidade (FMC 429) e a fórmula do reino dos fins (FMC 437). ${ }^{2}$ A primeira reza: “age apenas segundo uma máxima tal que possas ao mesmo tempo querer que ela se torne lei universal" (FMC 421). A segunda reza: "age de tal maneira que uses a humanidade, tanto na tua pessoa como na pessoa de qualquer outro, sempre simultaneamente como fim e nunca simplesmente como meio" (FMC 429). A terceira reza: "age segundo máximas de um membro universalmente legislador em ordem a um reino dos fins somente possível" (FMC 437). Se aplicarmos essas idéias à amizade estética do próprio Kant, que corresponde de modo geral à amizade com vistas à utilidade e ao prazer de Aristóteles, parece que temos um exemplo de um imperativo hipotético, em que portanto uma pessoa está sendo tratada como mero meio para atingir um fim. De fato parece, prima facie, que uso meu "amigo" para satisfazer minhas necessidades, o que faz dele um meio, isto é, retira dele sua humanidade. Mas acontece que se ele também me utiliza como meio a reciprocidade faz que cada um recupere sua humanidade. Vejamos o seguinte exemplo: na Doutrina do Direito, ao falar do casamento, Kant admite que o homem usa a mulher para satisfazer suas necessidades sexuais (DD 277), mas como ela também o usa para satisfazer as suas, ambos, que em princípio perdem sua humanidade por serem tratados como meio, recuperam-na de volta através da reciprocidade (DD 278). Ora, o caso da amizade estética é 
exatamente o mesmo: ela não é imoral se eu sou benevolente com meu amigo e ele é igualmente benevolente comigo. Se levarmos o argumento kantiano do casamento a sério, aplicando-o analogicamente ao caso da amizade estética, a reciprocidade não exige sequer que eu cumpra o dever por dever! Basta que ambos os amigos estejam cientes do caráter instrumental da amizade. Alguém poderia objetar que a segunda fórmula do imperativo categórico, a fórmula da humanidade, até admite que eu trate alguém como meio, mas não permite que eu o trate somente como meio; é preciso que eu o trate simultaneamente como fim. Mas poderia se dizer que quando em uma amizade estética ambos estão cientes da reciprocidade e do caráter estético da amizade, ambos estão sendo tratados um pelo outro simultaneamente como fim. Se voltarmos a Aristóteles podemos compreender essa questão mais facilmente. Após diferenciar os três tipos de amizade, Aristóteles admite que na amizade absoluta, isto é, amizade dos bons, pode haver também troca de utilidade. O problema é, como vimos, quando há engano e alguém que penso ser meu amigo em sentido absoluto é na verdade meu amigo com vistas à utilidade. Se eu tenho um amigo com vistas à utilidade e ele, reciprocamente, tem a mim como amigo com vistas à utilidade, embora estejamos tratando um ao outro como meio para satisfação de nossas necessidades, estamos, segundo o argumento do próprio Kant, recuperando nossa humanidade através da reciprocidade do tratamento como meio. Além disso, se estamos ambos cientes, através de manifestações explícitas ou implícitas do outro, que a amizade tem por objetivo a utilidade, estamos dizendo a verdade um para o outro e estamos nos tratando simultaneamente como fins. Poderia até mesmo se dizer que o simples fato de ambos estarem cientes do caráter utilitário dessa amizade faz dela de algum modo uma amizade moral, pois ambos os amigos estão sendo sinceros um para com o outro. $\mathrm{O}$ mesmo vale para a amizade com vistas ao prazer: uma relação sexual casual tem as mesmas características da amizade de utilidade apontadas acima. O problema ocorre quando há engano, isto é, quando uma parte se faz passar por amiga em sentido absoluto da outra, mas na verdade ela está se aproximando da outra para obter algum benefício, e a outra, acreditando na boa-fé da primeira, adota uma sincera intenção de amizade, adotando-a como amiga em sentido absoluto. Nesse caso, do ponto de vista de Kant, a primeira está tratando a segunda como mero 
meio, não havendo reciprocidade e recuperação, por parte da segunda, de sua humanidade perdida com o tratamento instrumental. Esse tipo de coisa aconteceria, na terminologia de Kant, quando um tem o outro como amigo em sentido estético enquanto o outro tem o primeiro como amigo no sentido moral.

Para seguir a análise dessas questões, preciso melhor analisar a concepção de Kant da amizade em sentido moral. É o que passo a fazer, através de uma análise da relação entre esta e as formas de amizade apresentadas nas Preleções.

Como vimos, na Doutrina da Virtude, Kant apresentou apenas dois tipos de amizade: (a') amizade estética e (b’) amizade moral; não há um terceiro tipo (não há um c'). Como também vimos, nas Preleções sobre Ética, Kant diferenciou três tipos de amizade: (a”) a amizade de necessidade ou confiança recíproca para a satisfação de necessidades da existência; (b") a amizade de gosto ou estética e (c") a amizade de intenção. Entendo que a (a") amizade de necessidade das Preleções corresponde à (a') amizade estética da Doutrina da Virtude. Porém, a meu ver, a (b') amizade moral da Doutrina da Virtude não engloba tanto a (b") amizade de gosto ou estética quanto a (c") amizade de intenção das Preleções, mas apenas esta última. Como vimos, Kant afirma que a (b") amizade de gosto não é uma verdadeira amizade, e sim uma pseudoamizade: ela não se funda na confiança mútua como a amizade moral da Doutrina da Virtude (à qual corresponde a amizade de intenção das Preleções), mas simplesmente na necessidade de partilhar experiências próprias com os demais. Ora, posso muito bem conversar casualmente com muitas pessoas sem com elas manter uma relação de confiança mútua como na amizade moral (ou amizade de intenção). A meu ver, a (b”) amizade de gosto das Preleções está inclusive mais próxima da (a’) amizade estética da Doutrina da Virtude que da (b') amizade moral.

Cumpre agora perguntar: pode a (b') amizade moral em Kant se combinar com a (a') amizade estética, do mesmo modo que a as amizades (a) com vistas à utilidade e (b) ao prazer podem se combinar com a (c) amizade absoluta em Aristóteles? Por um lado, como já vimos, podemos dizer que à amizade dos bons de Aristóteles corresponde a amizade moral de Kant. Naturalmente elas não são idênticas, mas há uma correspondência, pois Aristóteles fala da amizade que se funda na bondade mútua, 
amizade em sentido absoluto e não meramente relativo como as demais, e Kant fala da amizade moral como a "confiança total entre duas pessoas que revelam reciprocamente suas opiniões e sentimentos íntimos, na medida em que tais revelações sejam compatíveis com o respeito recíproco", exteriorizando assim uma bondade interna (DV 471). Embora a (c) amizade absoluta de Aristóteles pareça ser mais ampla que a (b') amizade moral de Kant, há em ambas, pelo menos aparentemente, um caráter desinteressado: o desejo do bem do outro. Antes de aprofundar a análise da reciprocidade que pode ou não estar envolvida na amizade moral, cumpre voltar à questão posta acima: pode uma amizade ser ao mesmo tempo moral e estética? Entendo que Kant pensa que não. Pelo menos não há nenhuma menção a isso na Doutrina da Virtude. Como vimos, Aristóteles expressamente o admite, o que propicia, a meu ver, um tratamento mais adequado da amizade. Ora, é no mínimo pouco razoável pensar que (c) verdadeiros amigos não podem (a) se ajudar mutuamente, isto é, não podem praticar mutuamente ações úteis um ao outro, ou ainda (b) obter prazer um do outro, ou ainda achar que (a) amigos com vistas à utilidade não podem (c) desejar honestamente o bem um do outro. $\mathrm{O}$ tratamento que Aristóteles dá à questão propicia portanto uma abordagem mais realista e sensata. Por outro lado, é preciso lembrar que ao enfatizar a impossibilidade prática da amizade estética Kant está de algum modo também contribuindo para uma abordagem realista da amizade, pois ao constatar que a desproporcionalidade na benevolência impede toda amizade estética ele nos ajuda a entender um importante problema prático da amizade: mesmo em uma amizade "mista", isto é, na linguagem Aristotélica, uma amizade absoluta que também trás utilidade e prazer mútuos ou, na linguagem de Kant, uma amizade moral em que se busque também a benevolência mútua (que Kant não concebe mas que aqui não só admito como entendo ser a mais viável na prática), a igualdade na benevolência e respeito é algo difícil de se alcançar.

Devo agora focar a questão da reciprocidade. Vimos, no início, que para Aristóteles a amizade implica reciprocidade. Para Kant, tanto a amizade estética quanto a amizade moral também a implicam. Christine Korsgaard chega a dizer que a idéia de que as relações pessoais são caracterizadas pela reciprocidade não só é um ponto importante tanto da teoria de Aristóteles quanto da teoria de Kant, como vai além e diz que 
eles são dos poucos filósofos que deram a devida importância a essa questão (KORSGAARD, 2000, p. 190). Mas, como vimos, em Kant a desproporcionalidade na benevolência, que pode ser vista como ausência de reciprocidade na quantidade da prestação, impede a existência da amizade estética. E na amizade moral? Que espécie de reciprocidade está em pauta? Ora, também a amizade moral exige reciprocidade, isto é, que ambos confiem um no outro, já que ela foi definida como "confiança total entre duas pessoas" (DV 471). E mesmo a amizade moral, que não é impossível de ser alcançada, é para Kant, como vimos, coisa rara, porque as pessoas não confiam a outras todos os seus segredos e/ou porque as outras não sabem guardar um segredo. É preciso, pois, uma confiança mútua. Um ponto importante aqui, que foi negligenciado por Kant, é que a amizade moral envolve também um problema psicológico: se alguém em que confio não confia em mim, isto é, se alguém para quem revelo meus segredos não revela a mim seus segredos, ou então se alguém para quem contei meus segredos os revela a terceiros sem minha autorização enquanto eu não revelo os seus segredos sem sua autorização, não há então amizade moral. Amizade moral e amizade estética não são portanto coisas tão diversas: pode-se dizer que quando alguém escuta os mais íntimos segredos de seu amigo o está de algum modo ajudando, e que quando respeita a escolha do amigo de não divulgar ou quando divulgar esse segredo a outros, o está de algum modo respeitando. Nesse sentido, a amizade moral de Kant se aproxima muito da amizade com vistas à utilidade de Aristóteles.

Como vimos, a amizade moral é para Kant coisa rara, tanto por causa da nossa necessidade de manter segredos quanto por causa da dificuldade dos outros de manter em segredo o que nós lhes contamos. Isso faz que tenhamos poucos amigos (DV 472) e ainda que aquele que é amigo de todos não tenha amigo particular (PE 224). Essa idéia já estava presente em Aristóteles: "não ser homem de muitos convidados, nem homem de nenhum” (ARISTÓTELES, 1991, p. 172). A amizade que parece ser possível, isto é, um misto de amizade moral com amizade estética (que Kant não admite) ou um misto de amizade com vistas à utilidade e ao prazer e amizade absoluta, que Aristóteles expressamente admite, envolve reciprocidade em um tal nível que de fato dificilmente será possível ter muitos amigos. Mas Kant cria um conceito novo para tentar resolver esse 
problema: o amigo da humanidade. Segundo Merle, a figura do amigo da humanidade implica uma mudança radical na noção de amizade: a renúncia à reciprocidade como condição de sua existência (MERLE, 2007, p. 48). Merle chega a dizer que, por causa do amigo da humanidade, a noção de amizade como relação entre um grupo limitado de pessoas é substituída, por Kant, por uma noção de amizade como modo de agir em relação a um grupo aberto, o que, embora geralmente negligenciado pelos intérpretes, constitui um momento decisivo da filosofia da amizade (MERLE, 2007, p. 37).

A amizade para com a humanidade não se confunde nem com o conceito moral nem com o conceito estético de amizade, conseguindo porém superar o problema das duas. Como vimos, para Kant, a expressão amigo dos seres humanos contém "a representação e o tomar a peito da igualdade entre os homens, portanto, a idéia de que ao obrigar outros com a beneficência se torna ele próprio obrigado; por assim dizer, como se todos os homens fossem irmãos sob o poder de um pai universal, que quer a felicidade de todos" (DV 473). Merle entende que a tríplice igualdade prevista na amizade estética está aqui assegurada: a imagem do pai universal representa a lei moral à qual estão todos os seres humanos submetidos: "o mérito moral de exercer a benevolência por dever e a obrigação de gratidão devida pelo beneficiário em razão da lei moral encontram seu correspondente no dever do benfeitor de obedecer à lei moral, que ordena, entre outras coisas, a benevolência" (MERLE, 2007, p. 49). Mas o fato de o beneficiário nem sempre se submeter à lei moral não é um argumento contra a amizade pela humanidade, porque, como ressalta Merle, a reciprocidade não faz parte do conceito semântico de amigo da humanidade (MERLE, 2007, p. 49). O amigo da humanidade é pois aquele que age moralmente, praticando a benevolência por que ela é um dever.

\section{Filia, Direito e Política}

Embora esse conceito de amigo da humanidade represente um abandono da idéia de reciprocidade, ele não implica, a meu ver, a entrada da amizade, pelo menos do modo como tratado por Kant, no domínio do direito e da política. Isso porque o amigo da humanidade é aquele que se submete à 
lei moral, não por causa da coerção, mas por causa da própria lei moral. Como se sabe, o direito é concebido, em Kant, como lei exterior dotada de coerção (MC 220; DD 232). Os deveres de virtude exigem, além da conformidade com o dever, a ação por dever (MC 219-220), e o fato da ação em conformidade com o dever ser praticada por dever é denominado moralidade da ação, enquanto, por outro lado, os deveres de direito exigem apenas a conformidade com o dever, e essa mera conformidade, que é denominada legalidade (MC 219), pode ser obtida através da possibilidade da força. Por isso o direito está necessariamente ligado à faculdade de coagir (DD 232). Mas a aceitabilidade da coerção decorre da necessidade de aceitação de uma aceitação recíproca universal do uso da força, para que os exercícios exteriores da liberdade de todos possam coexistir. No direito, embora não exista reciprocidade no mesmo sentido da reciprocidade exigida na moral, há uma espécie de reciprocidade que, podemos dizer, é uma reciprocidade transcendental, pois a lei não precisa de fato contar com a participação de todos, como em Rousseau, mas precisa poder contar com a participação de todos, isto é, tem que poder valer como lei universal. A reciprocidade presente no direito está ligada ao caráter transcendental da idéia de liberdade em Kant.

Como vimos na primeira parte deste ensaio, Aristóteles fala da unanimidade, que para ele é uma relação amigável. Ela não é entendida como mera identidade de opinião, mas sim como identidade de opinião quando as pessoas tratam de algo que é de seu interesse, e então escolhem as mesmas ações e fazem em comum o que resolveram (ARISTÓTELES, 1991, p. 165). Essa relação, que envolve obviamente o Direito, é considerada por Aristóteles uma espécie política de amizade. A questão que cumpre agora analisar é em que medida ela envolve reciprocidade? A meu ver, na mesma e exata medida que o direito a envolve, isto é, do modo descrito no parágrafo anterior. A reciprocidade envolvida na Doutrina do Direito de Kant, assim como a reciprocidade envolvida na noção de unanimidade de Aristóteles, é reciprocidade em um sentido fraco: ela não exige que eu partilhe com outro mutuamente grande confiança, troca de utilidade ou de prazer, mas sim a vontade de viver em comum, que decorre, tanto em Kant quanto em Aristóteles, da sociabilidade humana, e que demanda deliberação conjunta para tomada de decisões sobre políticas públicas, normas etc., porque, como mostra Kant, a sociabilidade é também insociável. 
Essa deliberação conjunta, em Kant, é feita através de um processo republicano, que se funda na vontade geral e que tem como objetivo efetivá-la. O que denominamos Democracia é pois uma decorrência de uma filosofia moral fundada na autonomia. Podemos dizer que essa noção republicanista de Kant se aproxima de algum modo da idéia de unanimidade de Aristóteles, pois ambas representam a idéia de uma sociedade política que autonomamente decide seu destino.

O tema da amizade envolve, como bem percebeu Kant nas Preleções, uma tensão entre o amor próprio e o amor pelos outros. Como vimos no início, também em Aristóteles aparece essa questão, que ele resolve com a diferenciação entre o sentido positivo e o sentido negativo de amor por si próprio. Não há, para Aristóteles, problema algum em amar a si mesmo, se isso quer dizer desejar a virtude, e não simplesmente riqueza, prazer ou poder. Kant não faz explicitamente essa diferenciação: quando, nas Preleções, fala da tensão acima referida, parece estar se referindo meramente ao querer a felicidade. Mas podemos dizer que a diferenciação de Aristóteles está, de algum modo, presente em Kant: o amigo da humanidade quer o bem dos outros do mesmo modo que o bem próprio. Mas se, por um lado, mesmo a introdução da noção de amigo da humanidade não parece significar a entrada da temática da amizade no âmbito do direito e da política, por outro lado não podemos esquecer que embora o direito e a política, em Kant, se separem da moral, eles se fundam nessa mesma moral.

Isso quer dizer que, mesmo tendo Kant colocado o tema da amizade na Doutrina da Virtude e não na Doutrina do Direito, é possível pelo menos estabelecer uma relação entre amizade, Direito e Política: assim como a unanimidade de Aristóteles, que claramente não envolve reciprocidade no sentido próprio ou forte do termo, mas sim em um sentido fraco, pode ser vista, como de fato foi vista, como uma forma da amizade política, também o direito e a política em Kant podem ser vistos como envolvendo essa mesma reciprocidade num sentido fraco, e, portanto, podem de algum modo ser relacionados à amizade. Se isso for verdade, o direito e a política em Kant envolvem, como em Aristóteles, um conceito especial de amizade: a amizade cívica. 
${ }^{1}$ As obras de Kant serão citadas pelas páginas da Edição da Academia (AA), após as iniciais da obra em português: MC para A Metafísica dos Costumes, e para as suas duas Partes, a Doutrina do Direito e a Doutrina da Virtude, respectivamente DD e DV; FMC para a Fundamentação da Metafísica dos Costumes e PE para as Preleções sobre Ética (Moralphilosophie Collins).

2 Alguns autores entendem serem cinco as fórmulas do imperativo categórico. Aqui sigo a idéia de Korsgaard de que elas são três (cf. KORSGAARD, 2000, p. 77-132).

\section{Referências bibliográficas}

ARISTÓTELES. 1991. Ética a Nicômaco. Coleção Os Pensadores. São Paulo: Nova Cultural.

BARON, M. 2002. "Love and Respect in the Doctrine of Virtue". In TIMMONS, M. org. Kant's Metaphysics of Morals. Oxford: Oxford University Press, p. 391-407.

KANT, I. 1995. Fundamentação da Metafísica dos Costumes. Trad. P. Quintela. Lisboa: Edições 70. 2005. A Metafísica dos Costumes. Trad. J. Lamego. Lisboa: Fundação Calouste Gulbenkian. . Moralphilosophie Collins (Nachschrift), Akademie-Ausgabe (AA), Bd. XXVII/1.

KORSGAARD, C. 2000. Creating the kingdom of ends. Cambridge: Cambridge University Press.

MERLE, J.-C. 2007. "A amizade nos limites da moral”. In: MERLE, J.C. e TRAVESSONI GOMES, A. (orgs.). A moral e o direito em Kant. Ensaios analíticos. Belo Horizonte: Mandamentos, p. 37-53. 